\title{
Effect of milk coagulation properties of herd bulk milks on yield and composition of Emmental cheese
}

\author{
Tiina Ikonen, Outi Ruottinen \\ Department of Animal Science, PO Box 28, FIN-00014 University of Helsinki, Finland, \\ e-mail: tiina.ikonen@helsinki.fi \\ Eeva-Liisa Syväoja, Kimmo Saarinen \\ Valio Ltd., Research and Development, PO Box 10, FIN-00039 Valio, Finland \\ Eero Pahkala \\ Agricultural Research Centre of Finland, Food Research, FIN-31600 Jokioinen, Finland \\ Matti Ojala \\ Department of Animal Science, PO Box 28, FIN-00014 University of Helsinki, Finland
}

\begin{abstract}
The effect of milk coagulation properties of herd bulk milks on cheese yield, and on composition of cheese and cheese whey was estimated using milks that were collected from two herd groups each consisting of 4 herds. The herd groups differed from one another in milk coagulation properties. Frequencies of $\alpha_{\mathrm{s} 1}$-casein $\mathrm{C}$ allele, $\beta$-casein $\mathrm{A}_{1}$ and $\mathrm{B}$ alleles, and $\kappa$-casein $\mathrm{B}$ allele; proportion of Finnish Friesian cows in a herd; and concentrations of $\kappa$-casein, $\alpha$-lactalbumin, and $\beta$-lactoglobulin were higher for the group with good milk coagulation properties than for that with poor properties. Two Emmental cheeses were made of milk of each group, and about 7401 of milk was used to produce one cheese. On average $2 \mathrm{~kg}$ more cheese was obtained from milk with good coagulation properties than from milk with poor properties. The dry matter content of the cheeses was higher, and the fat and casein contents in the cheese whey were lower for the well-coagulating than for the poorly coagulating milk. These observations suggest that improvement of coagulation properties of herd bulk milk would improve the efficiency of cheese-making.
\end{abstract}

Key words: cheese, cheese composition, cheese whey, cheese-making, coagulation properties, noncoagulation

\section{Introduction}

Variation in milk coagulation properties between individual cows has been rather well documented. Important factors that contribute to this var- iation are lactation stage, season, parity, feeding, udder health, breed, milk protein polymorphism, genetic level of cows, and composition of milk (Riddell-Lawrence and Hicks 1989, Jakob and Puhan 1992, Walsh et al. 1995, Ikonen et al. 1997, 1999a). The large variation in milk

(C) Agricultural and Food Science in Finland

Manuscript received June 1999 


\section{AGRICULTURAL AND FOOD SCIENCE IN FINLAND}

\section{Ikonen, T. et al. Effect of milk coagulation properties on yield and composition of cheese}

coagulation properties that was observed in a sample of 789 Finnish Ayrshire (FAy) cows was in part because $8 \%$ of the cows had produced non-coagulating milk (Ikonen et al. 1999a). Noncoagulating milk did not form curd within $30 \mathrm{~min}$ after addition of rennet to the milk. Non-coagulation of milk has been observed also by Okigbo et al. (1985), and Davoli et al. (1990).

Published results for the degree of variation in milk coagulation properties between various herds and for the factors that cause this variation are rare. In a sample of 51 herds, a large variation in milk coagulation properties among the herds was observed (Ikonen et al. 1999a). None of the studied factors, including breed, milk protein polymorphism, or composition of milk, fully explained this variation (Ikonen et al. 1999a). However, the $\kappa$-casein $(\mathrm{CN}) \mathrm{B}$ allele, that is rare (8\%) in the FAy (Ikonen et al. 1996), was more common in the herds with good milk coagulation properties than in those with poor properties (Ikonen et al. 1999a). Martin et al. (1997) found differences in milk coagulation properties between six herds, but the variation was smaller than that observed by Ikonen et al. (1999a). Variation in milk coagulation properties between herds can be important at least for small and medium-sized cheese plants. When the milk for cheese-making comes from a restricted number of farms, the proportional impact of milk from one farm on the average milk coagulation ability can be considerable (Puhan and Jakob 1993).

Milk coagulation properties have a rather clear effect on yield and composition of cheese; milk that coagulates quickly and effectively retains fat and $\mathrm{CN}$ in the coagulum is expected to produce higher cheese yields with more desirable composition than milk with unfavourable properties (Bynum and Olson 1982, Grandison 1986, Aleandri et al. 1989, Lucey and Kelly 1994, Martin et al. 1997).

In cheese-making experiments, cheeses have often been made using milk that was collected from rather small cow groups with certain milk protein genotypes or other characteristics (Marziali and Ng-Kwai-Hang 1986a and 1986b, Tong et al. 1993, Walsh et al. 1995, Mayer et al. 1997, Toivonen et al. 1998). Because of the rareness of some casein alleles (e.g., the $\kappa-\mathrm{CN}$ B allele), and linkage disequilibrium in the $\mathrm{CN}$ loci (Bovenhuis et al. 1992, Ikonen et al. 1999b), appropriate selection of cows according to $\mathrm{CN}$ genotypes can be difficult. In few studies milk was collected from various herds that differed in milk coagulation properties (Grandison et al. 1985, Martin et al. 1997). This selection procedure may, however, better reflect the true variation in milk coagulation properties within a milk supply area than selection by milk protein polymorphism.

The objective of this study was to estimate the effect of the coagulation properties of herd bulk milks on cheese yield, and on composition of cheese and cheese whey.

\section{Material and methods}

\section{Selection of herds for the cheese-making experiment}

The herds that would provide milk for the cheese-making experiment were chosen from 30 candidate herds with 10 or more FAy or Finnish Friesian (FFr) cows. The candidate herds were located along two milk collection routes of the dairy co-operative Alueosuuskunta Promilk (Lapinlahti, Finland). The objective was to find herds that differed as much as possible in milk coagulation properties and, if possible, only slightly in gross composition and SCC of milk.

Milk coagulation properties as well as fat and protein contents (Milko-Scan; Foss Electric A/ $\mathrm{S}$, Hillerød, Denmark) and somatic cell count (SCC) (Fossomatic cell counter; Foss Electric A/S) of the candidate herds' bulk milk were determined twice in February 1997. Milk coagulation properties (milk coagulation time, curdfirming time and firmness of the curd) were determined with a Formagraph (Foss Electric A/ S,) as described by Ikonen et al. (1999a). 
Vol. 8 (1999): 411-422.

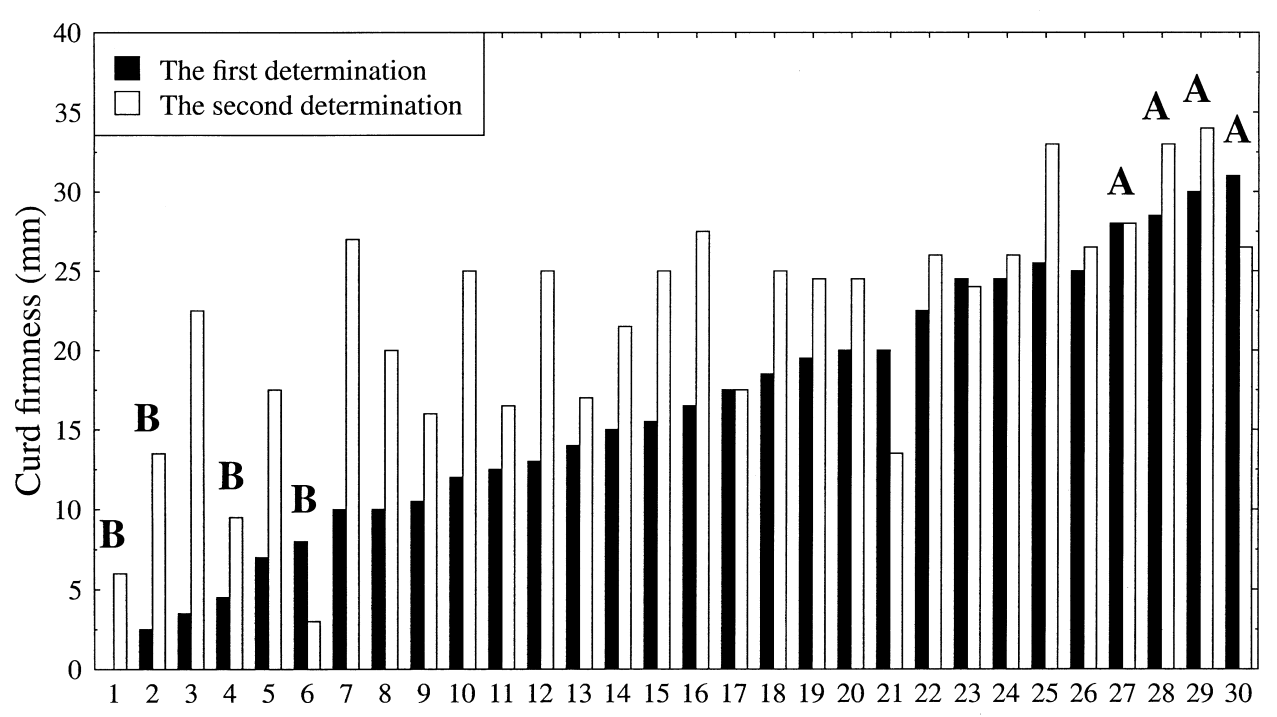

Fig. 1. Variation in curd firmness among the 30 candidate herds. The eight herds labelled with A or B (Group A = 27, 28, 29, 30; Group B = 1, 2, 4, 6) were chosen to the cheese-making experiment in March 1997.

The candidate herds varied considerably in milk coagulation properties (Fig. 1). The first test produced values for curd firmness ranging from $0.0 \mathrm{~mm}$ (non-coagulating milk) to $31.0 \mathrm{~mm}$, and the second from $3.0 \mathrm{~mm}$ to $34.0 \mathrm{~mm}$ (Fig. 1). Except for a few herds, milk coagulation properties were rather stable within each herd during the sampling period.

Of the candidate herds, 8 herds with extreme milk coagulation properties were chosen for the cheese-making experiment (Fig. 1). Group A consisted of 4 herds that had produced well-coagulating milk, and group B of 4 herds that had produced poorly coagulating milk on both previous determinations of milk coagulation properties (Fig. 1).

\section{Additional information about the chosen herds}

Information on parity, lactation stage, and breed for the cows in the chosen herds were obtained from the Agricultural Data Processing Centre (Vantaa, Finland).

\section{Collection of milks for the cheese-making experiment}

One essential objective of the collection of milk was to get equal amounts of milk from the herds of each group. Consequently, milk for the cheesemaking experiment was obtained in 2 to 6 consecutive milkings in both herd groups (Table 1). During the collection period the milk was kept at $4^{\circ} \mathrm{C}$ in the tanks of the farms.

The milk was collected on the $12^{\text {th }}$ of March in 1997. Milks of the two herd groups were collected separately in two tanks to avoid mixing. The herds of group A were somewhat larger than those of group B (Table 1). Consequently, 2800 1 of milk was collected from the herds of group A and 19001 of milk from those of group B. In addition, a milk sample was taken from the tank of each herd and from each cow in the herds.

The proportion of a single herd milk yield in the total milk yield in the herd group ranged from 15 to $35 \%$ in group A and from 15 to $33 \%$ in group B. In addition, even though the number of milkings varied somewhat in both herd groups, the average number of milkings differed only 
Ikonen, T. et al. Effect of milk coagulation properties on yield and composition of cheese

Table 1. Information on the herds that provided milk for the cheese-making experiment.

\begin{tabular}{|c|c|c|c|c|c|c|c|c|c|}
\hline \multirow[b]{2}{*}{ Herd } & \multicolumn{4}{|c|}{ GroupA } & \multicolumn{5}{|c|}{ Group B } \\
\hline & $\begin{array}{l}\text { No.of } \\
\text { cows }\end{array}$ & $\begin{array}{c}\text { Milk yield, } \\
\mathrm{kg}^{1}\end{array}$ & $\begin{array}{l}\text { No. of } \\
\text { milkings }\end{array}$ & $\begin{array}{c}\% \text { of } \\
\text { HMY }^{2}\end{array}$ & Herd & $\begin{array}{l}\text { No.of } \\
\text { cows }\end{array}$ & $\begin{array}{c}\text { Milk yield, } \\
\text { kg }\end{array}$ & $\begin{array}{l}\text { No. of } \\
\text { milkings }\end{array}$ & $\begin{array}{l}\% \text { of } \\
\text { HMY }\end{array}$ \\
\hline 1 & 22 & 970 & 4 & 35 & 5 & 9 & 624 & 6 & 33 \\
\hline 2 & 14 & 633 & 4 & 23 & 6 & 9 & 281 & 4 & 15 \\
\hline 3 & 13 & 766 & 6 & 27 & 7 & 13 & 548 & 6 & 29 \\
\hline 4 & 16 & 420 & 2 & 15 & 8 & 14 & 418 & 2 & 22 \\
\hline
\end{tabular}

Milk yield collected for the cheese-making experiment

2 Proportion of the milk yield produced in a herd in the total milk yield in the herd group

slightly between group A (4.0 milkings) and group B (4.5 milkings). Consequently, the collection of the milks from the two herd groups was quite successful concerning the age and the relative volume of the milks produced in the 8 herds.

\section{Cheese-making}

The cheeses were made on the $13^{\text {th }}$ of March at a pilot-scale cheese plant, which is a part of the commercial cheese plant of Valio Ltd. in Lapinlahti. Because there were two cheese vats at the pilot-scale cheese plant, it was possible to make two cheeses simultaneously. The vats were composed of two adjacent round tanks that were joined to each other.

Two Emmental cheeses were first made of milk with good coagulation properties (milk A) and then two cheeses of milk with poor properties (milk B). In total, 640 to 6501 of herd bulk milk was used to produce one cheese. The first pair of cheeses was made in 4 to 5 hours, during which time milk B was kept cool in a tank. The second pair of cheeses was made immediately after the first one. Cheese-making conditions were identical for each vat.

The cheeses were made according to a procedure that is used in Emmental production at the commercial cheese plant of Valio Ltd. in Lapinlahti. The milks were first thermisised at
$63 \pm 1{ }^{\circ} \mathrm{C}$. Because the fat content of thermisised milk A $(4.07 \%)$ did not differ from that of milk B $(4.08 \%)$, all milks were standardised by adding 1001 of skimmed bulk milk. The skimmed bulk milk was pooled milk that was used for standardisation in Emmental production at the commercial cheese plant on the cheese-making day. After standardisation, samples were taken for chemical analyses.

The standardised milks were inoculated with Streptococcus thermophilus T101, Lactobacillus helveticus K16, Lactobacillus rhamnosus LC705, and Propionibacterium freudenreichii ssp. freudenreichii 131. The starters are produced by Valio Ltd. and are used in Emmental production at the commercial cheese plant of Valio Ltd. in Lapinlahti. About 20 minutes later, $45 \mathrm{ml}$ Thermolase (Endothia parasitica protease) rennet (Sanofi/Bio-Industries, Laboratories Granday-Roger, La Ferte sous Jouarre, France) was added, and the milks were allowed to coagulate at $31.5^{\circ} \mathrm{C}$.

The firmness of the coagulums was assessed by an experienced cheesemaker by observing the effect of cutting with a spatula. All coagulums were cut mechanically $35 \mathrm{~min}$ after addition of rennet, even though the curds of milk B were at that point somewhat softer than those of milk A. In commercial cheese production in Finland, coagulums are cut after a fixed time (in Emmental production usually about $30 \mathrm{~min}$ after addition of rennet) unless curd firmness varies considerably between the cheese vats. 
Vol. 8 (1999): 411-422.

The curd-whey mixtures were cooked and stirred at $31.5^{\circ} \mathrm{C}$ for $50 \mathrm{~min}$, and 751 of water was added to each mixture. During the following $100 \mathrm{~min}$ the curd-whey mixtures were cooked and stirred at 49.5 to $54^{\circ} \mathrm{C}$. The curds were then separated from the cheese whey and moved to round cheese moulds. During the separation of the cheeses and cheese whey, several samples of the cheese whey were taken in order to get representative samples for chemical analyses.

The cheeses were pressed at a pressure of about $10 \mathrm{kPa}$ for $14 \mathrm{~h}$ at $30^{\circ} \mathrm{C}$, after which the fresh cheeses were weighed and samples for chemical analyses were taken. The cheeses were kept in brine (salt concentration of 20\%) for 24 $\mathrm{h}$ and were then packed into vacuum plastic bags. The cheeses were ripened according to the standard procedure (at $25^{\circ} \mathrm{C}$ for $4 \mathrm{~d}$, at $9^{\circ} \mathrm{C}$ for $6 \mathrm{~d}$, at 23 to $25^{\circ} \mathrm{C}$ for $36 \mathrm{~d}$ and at $5^{\circ} \mathrm{C}$ for $6 \mathrm{~d}$ ), after which samples for chemical and sensory analyses were taken.

\section{Chemical analyses}

Standardised milk. The four batches of standardised milk were analysed for milk coagulation properties (Formagraph), pH, SCC (Fossomatic cell counter; Foss Electric A/S), and for contents of 1) dry matter, fat and protein (Milko-Scan; Foss Electric A/S), 2) whey and CN (IDF standards 29:1964 and 20B:1993), 3) $\alpha_{\mathrm{s} 1^{-}}, \alpha_{\mathrm{s} 2^{-}}, \beta-$ and $\kappa-\mathrm{CN}, \alpha$-lactalbumin and $\beta$ lactoglobulin (LG), 4) ash, calcium and phosphorus (IDF standard 154:1992, Waters method C-207 (Waters; Millipore, Massachusetts, USA), and Waters method A-101, respective1y). Concentrations of $\mathrm{CN}$ components were determined by multiplying relative proportions of individual $\mathrm{CN}$ in total $\mathrm{CN}$ by $\mathrm{CN}$ content. Relative proportions of individual $\mathrm{CN}$ were determined by fast protein liquid chromatography (FPLC) (Pharmacia Biotech, Uppsala, Sweden) as described by Syväoja (1992). Individual whey proteins were fractionated by FPLC as described by Syväoja and Korhonen (1994).
Fresh and ripened cheeses. The fresh and ripened cheeses were analysed for contents of 1) dry matter (IDF standard 21B:1987), 2) fat (IDF Standard 5B:1986), 3) protein (IDF Standard 20B:1993), 4) ash (for fresh cheeses only; IDF standard 27:1964), 5) calcium (Atom absorption spectrometry method, IDF standard 154:1992), and 6) phosphorus (IDF standard 42B:1990). In addition, the ripened cheeses were assessed for interior appearance, texture and taste by two experienced evaluators that had been trained by Valio Ltd.

Cheese whey. The cheese whey samples were analysed for contents of 1) dry matter (IDF standard 21B:1987), 2) fat (IDF standards 1C:1987 and 16C:1987), 3) protein (N-analyser LECO F428; LECO, St. Joseph, Michigan, USA); 4) CN, and 5) caseinomacropeptide. $\mathrm{CN}$ content was determined by ultracentrifuging $100 \mathrm{ml}$ of cheese whey. After ultracentrifuging, most of the whey was decanted, and residual whey and fat were extracted from $\mathrm{CN}$ twice with $5 \mathrm{ml}$ of diethyl ether. The remaining $\mathrm{CN}$ was then weighed. $\mathrm{Ca}-$ seinomacropeptide content was determined by the method described by Outinen et al. (1995).

Other analyses. The milk samples that were taken from the tank of each herd were analysed for milk coagulation properties (Formagraph). The milk samples of the individual cows in the chosen herds were used to determine genotypes of $\alpha_{\mathrm{s} 1}{ }^{-}, \beta-$ and $\kappa-\mathrm{CN}$, and $\beta$-LG by using the method described by Erhardt (1989).

\section{Statistical analyses}

The statistical significance of the differences between group A and group B in the studied characteristics was determined using one-way analyses of variance and F test. For the characteristics that described the chosen herds (Table 2), the number of observations in a herd group was either four or equal to the total number of cows in the group. For the cheese-making characteristics (Tables 3 and 4), the number of observations in a herd group was two. 
Ikonen, T. et al. Effect of milk coagulation properties on yield and composition of cheese

Table 2. Characteristics of the herds in group $A(n=4)$ with good milk coagulation properties and of those in group B (n=4) with poor properties.

\begin{tabular}{|c|c|c|c|c|c|c|c|c|}
\hline \multirow{2}{*}{ Trait } & & \multicolumn{3}{|c|}{ Group A } & \multicolumn{3}{|c|}{ Group B } & \multirow[b]{2}{*}{$F$ test $^{1}$} \\
\hline & & Mean & (Min & Max) & Mean & (Min & Max) & \\
\hline \multirow{4}{*}{\multicolumn{2}{|c|}{$\begin{array}{l}\text { Curd firmness, } \mathrm{mm}^{2} \\
\text { Fat content, } \%^{2} \\
\text { Protein content, } \%^{2} \\
\text { Somatic cell count }(* 1000) \text {, cells } / \mathrm{ml}^{2}\end{array}$}} & 21.5 & $(17.0$ & $25.0)$ & 0.0 & $(0.0$ & $0.0)$ & $* * *$ \\
\hline & & 4.02 & $(3.87$ & 4.21) & 4.34 & $(3.75$ & 4.75) & ns. \\
\hline & & 3.23 & $(3.22$ & $3.26)$ & 3.32 & (3.11 & $3.46)$ & ns. \\
\hline & & 293 & $(62$ & 118) & 111 & $(78$ & 148) & ns. \\
\hline \multirow{2}{*}{\multicolumn{2}{|c|}{$\begin{array}{l}\text { Parity }^{3} \\
\text { Lactation stage, } \mathrm{d} \text { after calving }^{3}\end{array}$}} & 2 & $(1$ & 5) & 2 & $(1$ & 5) & ns. \\
\hline & & 171 & $(13$ & 421) & 177 & (8 & 561) & ns. \\
\hline \multicolumn{2}{|c|}{$\begin{array}{l}\text { Proportion of } \mathrm{FFr}^{4} \text { cows, } \% \\
\text { Milk protein allele frequencies }\end{array}$} & 86 & $(68$ & 100) & 18 & $(0$ & 50) & $* *$ \\
\hline \multirow[t]{3}{*}{$\kappa-\mathrm{CN}^{5}$} & A & 0.68 & $(0.61$ & $0.81)$ & 0.77 & $(0.61$ & $0.86)$ & ns. \\
\hline & B & 0.19 & $(0.12$ & $0.25)$ & 0.04 & $(0.00$ & $0.08)$ & $* *$ \\
\hline & $\mathrm{E}$ & 0.13 & $(0.06$ & $0.18)$ & 0.19 & $(0.11$ & $0.33)$ & ns. \\
\hline \multirow[t]{3}{*}{$\beta-\mathrm{CN}$} & $\mathrm{A}_{1}$ & 0.49 & $(0.38$ & $0.61)$ & 0.31 & $(0.19$ & $0.44)$ & $*$ \\
\hline & $\mathrm{A}_{2}$ & 0.50 & $(0.39$ & $0.63)$ & 0.69 & $(0.56$ & $0.81)$ & $*$ \\
\hline & $\mathrm{B}^{2}$ & 0.02 & $(0.00$ & $0.04)$ & 0.00 & $(0.00$ & $0.00)$ & ns. \\
\hline \multirow{2}{*}{$\alpha_{s 1}-\mathrm{CN}$} & B & 0.89 & $(0.73$ & 0.94) & 0.98 & $(0.94$ & $1.00)$ & $(*)$ \\
\hline & $\mathrm{C}$ & 0.12 & $(0.06$ & $0.27)$ & 0.02 & $(0.00$ & $0.06)$ & $(*)$ \\
\hline \multirow[t]{2}{*}{$\beta-\mathrm{LG}^{6}$} & A & 0.44 & $(0.29$ & $0.56)$ & 0.29 & $(0.06$ & 0.39) & ns. \\
\hline & $\mathrm{B}$ & 0.56 & $(0.44$ & $0.71)$ & 0.71 & $(0.61$ & 0.94) & ns. \\
\hline
\end{tabular}

1 Statistical significance for the difference in the characteristics between the groups.

2 Non-standardised bulk milk samples.

3 Number of observations is 67 for Group A (= the total number of cows in the group) and 45 for Group B (= the total number of cows in the group).

4 Finnish Friesian.

5 Casein.

6 Lactoglobulin.

$* * * \mathrm{P}<0.001, * * \mathrm{P}<0.01, * \mathrm{P}<0.05$, (*) $\mathrm{P}<0.10$, and ns. non-significant.

\section{Results and discussion}

\section{Characteristics of the herds}

None of the individual herd bulk milks of Group B coagulated, whereas those of Group A coagulated moderately (Table 2). Fat and protein contents and somatic cell count of milk did not differ between the two groups (Table 2).

There was no difference in average parity or lactation stage of the cows between the groups (Table 2). Even though the lactation stages of the cows were quite evenly spread along lactation, about $40 \%$ of the cows were in mid lactation in both groups. In previous Finnish studies, milk coagulation properties were at their weakest in mid lactation (Ikonen et al. 1997, 1999a, Tyrisevä et al. 1999). This could in part explain why milk coagulation properties of the chosen herds were somewhat poorer during cheese-making in March (Table 2) than they had been dur- 
Vol. 8 (1999): 411-422.

ing the selection period in February (Fig. 1). The average value for curd firmness of group A was of the same magnitude as those previously reported for milks of individual cows (Ikonen et al. 1997, 1999a).

The $\alpha_{\mathrm{s} 1}-\mathrm{CN} \mathrm{C}$ allele, the $\beta-\mathrm{CN} \mathrm{A}_{1}$ and $\mathrm{B}$ alleles, and the $\kappa-\mathrm{CN} B$ allele were more frequent in the herds of group A than in those of group B (Table 2). The favourable association of the $\beta$ $\mathrm{CN} \mathrm{A}_{1}, \beta-\mathrm{CN} \mathrm{B}$, and $\kappa-\mathrm{CN} \mathrm{B}$ alleles with curd firmness was in agreement with the results of some other studies (Tervala et al. 1985, Davoli et al. 1990, Ikonen et al. 1997, 1999a). According to Marziali and Ng-Kwai-Hang (1986a, $1986 b)$, the $\beta-C N A_{1} A_{1}$ and $\kappa-C N$ BB genotypes were associated with the most favourable cheese making properties. The $\kappa-\mathrm{CN}$ E allele was somewhat more common in the herds of group B than in those of group A, which was in agreement with the results reported by Ikonen et al. (1999a). The $\kappa-\mathrm{CN}$ E allele is rather common (about $30 \%$ ) in the FAy (Ikonen et al. 1996), the main dairy breed in Finland.

The differences in the casein allele frequencies between the herd groups were, in part, due to a higher proportion of FFr cows in group A than in group B. Among the FFr cows of this study $(n=65)$ the $\alpha_{\mathrm{s} 1}-\mathrm{CN} \mathrm{C}$ allele, the $\beta-\mathrm{CN} \mathrm{A}_{1}$ and $\mathrm{B}$ alleles, and the $\kappa-\mathrm{CN} \mathrm{B}$ allele were more frequent $(0.13,0.51,0.02$, and 0.17 , respectively) than among the FAy cows $(n=47)(0.00,0.28$, 0.00 and 0.09 , respectively). Because of the structure of the data of this study, effects of breed and milk protein polymorphism on the studied traits were thus confounded. In addition, because of linkage disequilibrium in the $\mathrm{CN}$ loci, certain casein alleles may appear together more often than expected when a random combination of casein alleles is assumed (Bovenhuis et al. 1992, Ikonen et al. 1999b). Because of the small data of our study, it was impossible to determine the casein haplotypes for the cows. In addition, it was impossible to simultaneously estimate the effects of the casein alleles to see whether each previous allele $\left(\alpha_{\mathrm{s} 1}-\mathrm{CN} \mathrm{C}, \beta-\mathrm{CN} \mathrm{A}_{1}\right.$ and $\mathrm{B}$, and $\kappa-\mathrm{CN} B$ ) actually had a favourable effect on milk coagulation properties.

\section{Standardised millks}

Thermisation and standardisation improved coagulation properties of the milks slightly, but the difference in curd firmness between the groups was still considerable (Table 3). Concentrations of $\kappa$-CN, $\alpha$-lactalbumin, and $\beta$-LG were higher in A milks than in B milks (Table 3). SCC was low in the milks of both groups.

\section{Fresh and ripened cheeses}

On average $2 \mathrm{~kg}$ more fresh cheese was yielded from milk A than from milk B (Table 4). This difference was not statistically significant, because only one of the cheeses made of milk B was clearly smaller than those made of milk A. An association between firm curd and high cheese yield has been reported by Okigbo et al. (1985), Aleandri et al. (1989), and Nsofor (1989). According to Mitchell et al. (1986), bulk milks with long coagulation time and high SCC were associated with lower cheese yield and higher moisture content of the cheeses than those with short coagulation time and low SCC. In the present study, SCC did not explain the difference in milk coagulation properties or cheese yield between the herd groups.

The dry matter content was higher in the cheeses of milk A (A cheeses) than in those of milk B (B cheeses) (Table 4). All milks were standardised to the same fat content, so the coagulums of milk A could entrap about $6 \%$ units more fat than could those of milk B. The association between the firm curd and the high dry matter content of the cheese that was observed in this study was also reported by Martin et al. (1997) and Walsh et al. (1995). According to Zehren (1993), increasing the fat transfer \% is one of the most effective ways to maximise the cheese yields and consequently the revenues of a cheese dairy.

The moisture content in non-fat substance was lower in A cheeses than in B cheeses (Table 4). According to Kefford et al. (1995), a 
Ikonen, T. et al. Effect of milk coagulation properties on yield and composition of cheese

Table 3. Characteristics of the standardised milks of group A $(n=2)$ with good milk coagulation properties and of those of group B $(n=2)$ with poor properties.

\begin{tabular}{|c|c|c|c|c|c|c|c|}
\hline \multirow[b]{2}{*}{ Trait } & \multicolumn{3}{|c|}{ Group A } & \multicolumn{3}{|c|}{ Group B } & \multirow[b]{2}{*}{$F$ test $^{1}$} \\
\hline & Mean & (Min & Max) & Mean & (Min & Max) & \\
\hline Curd firmness, mm & 27.5 & $(26.5$ & 28.5) & 2.5 & $(1.5$ & 3.5) & $* *$ \\
\hline Dry matter content, $\%$ & 12.43 & (12.28 & 12.57) & 12.25 & $(12.08$ & 12.41) & ns. \\
\hline Fat content, $\%$ & 3.59 & $(3.54$ & $3.64)$ & 3.61 & $(3.54$ & $3.67)$ & ns. \\
\hline Protein content, \% & 3.25 & $(3.20$ & $3.30)$ & 3.20 & $(3.17$ & $3.22)$ & ns. \\
\hline Somatic cell count $(* 1000)$, cells $/ \mathrm{ml}$ & 70 & $(65$ & 75) & 88 & $(80$ & 96) & ns. \\
\hline $\mathrm{pH}$ & 6.67 & $(6.66$ & $6.67)$ & 6.67 & $(6.67$ & $6.67)$ & ns. \\
\hline Ash content, $\%$ & 0.73 & $(0.73$ & $0.73)$ & 0.72 & $(0.71$ & $0.73)$ & ns. \\
\hline Calcium content, mg/100 g & 110 & $(107$ & 112) & 102 & (96 & 108) & ns. \\
\hline Phosphorus content, $\mathrm{mg} / 100 \mathrm{~g}$ & 85 & $(82$ & 87) & 79 & $(75$ & $82)$ & ns. \\
\hline Whey protein content, $\%$ & 0.51 & $(0.51$ & $0.51)$ & 0.50 & $(0.49$ & $0.50)$ & ns. \\
\hline Casein content, $\%$ & 2.59 & $(2.57$ & $2.60)$ & 2.53 & $(2.49$ & $2.57)$ & ns. \\
\hline$\alpha_{s 1}$-casein content, $\mathrm{g} / 100 \mathrm{~g}$ & 41.2 & $(41.0$ & 41.3) & 41.5 & $(40.7$ & 42.2) & ns. \\
\hline$\alpha_{s 2}$-casein content, $\mathrm{g} / 100 \mathrm{~g}$ & 11.6 & $(11.0$ & 12.2) & 12.7 & $(12.6$ & 12.8) & ns. \\
\hline$\beta$-casein content, $\mathrm{g} / 100 \mathrm{~g}$ & 34.1 & $(33.4$ & $34.7)$ & 33.8 & $(33.0$ & $34.5)$ & ns. \\
\hline K-casein content, $\mathrm{g} / 100 \mathrm{~g}$ & 13.2 & $(12.9$ & 13.4) & 12.1 & $(12.0$ & 12.1) & $*$ \\
\hline$\alpha$-lactalbumin content, $\mathrm{mg} / 100 \mathrm{ml}$ & 106 & $(105$ & 106) & 100 & $(100$ & 100) & $* *$ \\
\hline$\beta$-lactoglobulin content, $\mathrm{mg} / 100 \mathrm{ml}$ & 416 & (411 & 420) & 386 & $(384$ & $387)$ & $*$ \\
\hline
\end{tabular}

1 Statistical significance for the difference in the characteristics between the groups.

** $\mathrm{P}<0.01, * \mathrm{P}<0.05$, and ns. non-significant.

low moisture content in non-fat substance of a cheese is due to favourable syneresis properties of the milk used for cheese-making. Higher concentrations of ash, calcium and phosphorus in A milks than in B milks (Table 3) were reflected in higher concentrations of these minerals in fresh and ripened A cheeses than in B cheeses (Table 4).

\section{Cheese whey}

Less fat and $\mathrm{CN}$ were lost in the cheese whey of A cheeses than in that of B cheeses (Table 4). This result was in agreement with the results reported by Berg (1993) and Walsh et al. (1995). According to Lawrence et al. (1993), the most important step in estimating the efficiency of a cheese-making process is to measure the residual $\mathrm{CN}$ and fat lost in the cheese whey.

\section{Sensory analyses}

There was no difference in the sensory properties of the cheeses between the herd groups (Table 4). Even though B cheeses got a remark on roughness, all cheeses were of good quality and would have been acceptable for sale. Martin et al. (1997) did not find any clear association between milk coagulation properties and sensory properties of cheeses. The cheese-making technology used and the type of cheese made in our study differed from those in Martin et al. (1997).

\section{General discussion}

For practical reasons, the number of cheeses had to be restricted to four in this study. The volume of the milk that was used for making one cheese 
Vol. 8 (1999): 411-422.

Table 4. Average yield of the fresh cheeses, composition of the fresh and ripened cheeses and cheese whey, and sensory analyses of the ripened cheeses for group A $(n=2)$ with good milk coagulation properties and of those for group B ( $n=2)$ with poor properties.

\begin{tabular}{|c|c|c|c|c|c|c|c|}
\hline \multirow[b]{2}{*}{ Trait } & \multicolumn{3}{|c|}{ Group A } & \multicolumn{3}{|c|}{ Group B } & \multirow[b]{2}{*}{$F$ test $^{1}$} \\
\hline & Mean & (Min & Max) & Mean & (Min & Max) & \\
\hline \multicolumn{8}{|l|}{ Fresh cheese } \\
\hline Yield, kg & 68.9 & $(68.9$ & 68.9) & 66.9 & $(65.1$ & 68.7) & ns. \\
\hline Yield, $\mathrm{kg} / 1001$ milk & 9.3 & $(9.3$ & $9.3)$ & 9.0 & $(8.7$ & $9.3)$ & ns. \\
\hline Dry matter yield, kg/100 1 milk & 6.0 & $(6.0$ & $6.0)$ & 5.7 & $(5.5$ & 5.9) & ns. \\
\hline Dry matter content, $\%$ & 64.1 & $(64.0$ & $64.2)$ & 62.9 & $(62.6$ & $63.2)$ & $(*)$ \\
\hline Dry matter recovery, $\%$ & 46.6 & $(45.9$ & 47.2) & 44.9 & $(43.9$ & $45.8)$ & ns. \\
\hline Fat content, \% & 34.3 & $(34.2$ & 34.4) & 33.3 & $(32.7$ & 33.8) & ns. \\
\hline Fat recovery, \% & 86.2 & $(85.3$ & 87.2) & 80.5 & $(78.2$ & 82.9) & ns. \\
\hline Protein content, $\%$ & 26.3 & $(26.1$ & 26.4) & 26.3 & $(26.1$ & 26.4) & ns. \\
\hline Protein recovery, $\%$ & 72.9 & $(71.4$ & 74.4) & 71.7 & $(70.5$ & 72.9) & ns. \\
\hline Moisture in non-fat substance, $\%$ & $6 \quad 51.0$ & $(50.9$ & $51.0)$ & 52.1 & $(51.9$ & $52.2)$ & $*$ \\
\hline Ash content, \% & 2.80 & $(2.79$ & $2.80)$ & 2.67 & $(2.66$ & 2.68) & ** \\
\hline Calcium content, $\mathrm{mg} / 100 \mathrm{~g}$ & 880 & $(880$ & 880) & 815 & $(810$ & 820) & ** \\
\hline Phosphorus content, $\mathrm{mg} / \mathrm{kg}$ & 5750 & $(5700$ & $5800)$ & 5400 & $(5400$ & $5400)$ & $*$ \\
\hline \multicolumn{8}{|l|}{ Ripened cheese } \\
\hline Dry matter content, $\%$ & 64.5 & $(64.4$ & 64.5) & 63.4 & $(63.2$ & 63.7) & $(*)$ \\
\hline Fat content, \% & 34.6 & $(34.5$ & 34.7) & 33.5 & $(33.0$ & $34.0)$ & ns. \\
\hline Protein content, \% & 26.2 & $(26.1$ & 26.3) & 27.1 & $(26.6$ & 27.5) & ns. \\
\hline Calcium content, mg/kg & 8950 & $(8900$ & $9000)$ & 8550 & $(8500$ & $8600)$ & $* *$ \\
\hline Phosphorus content, $\mathrm{mg} / \mathrm{kg}$ & 5700 & $(5700$ & $5700)$ & 5500 & $(5500$ & $5500)$ & $*$ \\
\hline Interior appearance ${ }^{2}$ & 5 & $(5$ & 5) & 3 & (3 & 3) & ns. \\
\hline Texture & 4 & (4 & 4) & 4 & $(4$ & 4) & ns. \\
\hline Taste & 5 & $(5$ & 5) & 5 & $(5$ & 5) & ns. \\
\hline Remarks & & & & rough & & & \\
\hline \multicolumn{8}{|l|}{ Cheese whey } \\
\hline Dry matter content, $\%$ & 5.52 & $(5.03$ & $6.01)$ & 5.93 & $(5.87$ & 5.99) & ns. \\
\hline Fat content, $\%$ & 0.30 & $(0.27$ & $0.32)$ & 0.54 & $(0.50$ & $0.58)$ & $*$ \\
\hline Protein content, $\%$ & 0.65 & $(0.60$ & $0.69)$ & 0.67 & $(0.65$ & $0.69)$ & ns. \\
\hline $\begin{array}{l}\text { Caseinomacropeptide content, } \\
\mathrm{mg} / 100 \mathrm{ml}\end{array}$ & 79 & $(75$ & 82) & 69 & (68 & 70) & ns \\
\hline Casein content, $\mathrm{mg} / 100 \mathrm{ml}$ & 68 & $(59$ & $76)$ & 102 & $(99$ & 104) & $(*)$ \\
\hline
\end{tabular}

1 Statistical significance for the differences in the characteristics between the groups.

2 Points for sensory analyses are from 1 to $5 ; 1$ is the worst and 5 the best value.

** $\mathrm{P}<0.01, * \mathrm{P}<0.05$, and (*) $\mathrm{P}<0.10$, ns. non-significant.

was, however, large compared to that of other studies (e.g., Marziali and Ng-Kwai-Hang 1986a, 1986b). In addition, the milks used for cheese making were collected from several herds that were of reasonable size in Finnish conditions. However, the results of this study have to be interpreted carefully in order to draw reasonable conclusions concerning the differences in the studied characteristics between the herd groups. In addition, it would be useful to repeat the cheese-making experiment to confirm the results of this study.

Before making the cheeses, it was decided that each coagulum would be cut about $30 \mathrm{~min}$ 


\section{AGRICULTURAL AND FOOD SCIENCE IN FINLAND}

\section{Ikonen, T. et al. Effect of milk coagulation properties on yield and composition of cheese}

after rennet addition if they all were firm enough to be cut. Because the cheeses were made according to a procedure that is used in commercial Emmental production, it was thus possible to mimic the commercial cheese-making process. Consequently, it was possible to extrapolate the differences in the studied characteristics between the herd groups to large-scale cheese production.

The herds in group A and in group B differed from one another in milk coagulation properties. The non-standardised milks of group B did not coagulate, whereas the corresponding milk from group A coagulated moderately. The difference in milks coagulation properties between the groups was reflected in the difference in the composition of cheese and cheese whey between them. In addition, although the differences in consumption of milk and in cheese yield between the groups were not statistically significant, they would be remarkable if extrapolated to largescale cheese production. Because of the limited data it was, however, not reasonable to calculate any exact figures for the differences in the cheese-making properties between the groups at factory level.

A few factors were in part responsible for the differences in cheese-making efficiency between the herd groups; milk protein polymorphism, breed, and protein and mineral composition of milk. These factors were confounded, and because of the small data it was not possible to disentangle them from one another. In addition to these factors, various environmental factors like management and feeding may have been responsible for the differences in milk coagulation and cheese-making properties between the herd groups.

Some of the factors that caused the variation in coagulation and cheese-making properties of the milks could possibly be utilised to permanently improve the efficiency of cheese production. The milk coagulation properties themselves are well-inherited and repeatable traits (Ikonen et al. 1997, 1999a). If equipment for routine measurement of milk coagulation properties were available, good milk coagulation properties could be one breeding objective of the dairy cattle. The $\kappa-\mathrm{CN} \mathrm{B}$ allele, which can be determined for animals of both sexes and all ages, could be favoured to indirectly improve coagulation and cheese-making properties of milk. The rareness of the $\kappa-\mathrm{CN} \mathrm{B}$ allele in the FAy (Ikonen et al. 1996) might, however, restrict selection for that allele. Current methods for the determination of concentrations of individual proteins or minerals are not suitable for routine screening of a dairy cattle population. Consequently, at the moment these characteristics can not be improved by breeding.

In conclusion, a wide variation in milk coagulation properties between herds, and an effect of this variation on cheese-making properties were observed in this study. These observations suggest that improvement of coagulation properties of herd bulk milk would improve the efficiency of cheese-making.

Acknowledgements. The authors want to thank Alueosuuskunta Promilk for collecting the milks and Aimo Tiilikka for making the cheeses. This study was partially funded by the Ministry of Agriculture and Forestry (Helsinki, Finland).

\section{References}

Aleandri, R., Schneider, J.C. \& Buttazzoni, L.G. 1989. Evaluation of milk for cheese production based on milk characteristics and Formagraph measures. Journal of Dairy Science 72: 1967-1975.

Berg, G. van den 1993. Genetic polymorphism of $\kappa$-casein and $\beta$-lactoglobulin in relation to milk composition and cheesemaking properties. In: Proceedings of a IDF Seminar Cheese yield \& factors affecting its control, Cork, Ireland, pp. 123-133.

Bovenhuis, H., Arendonk J.A.M. van \& Korver S. 1992. Associations between milk protein polymorphisms and milk production traits. Journal of Dairy Science 75: 2549-2559.

Bynum, D.G. \& Olson, N.F. 1982. Influence of curd firmness at cutting on Cheddar cheese yield and recovery of milk constituents. Journal of Dairy Science 65: 


\section{AGRICULTURAL AND FOOD SCIENCE IN FINLAND}

Vol. 8 (1999): 411-422.

2281-2290

Davoli, R., Dall'Olio, S. \& Russo, V. 1990. Effect of $\kappa^{-}$ casein genotype on the coagulation properties of milk. Journal of Animal Breeding and Genetics 107: 458464.

Erhardt, G. 1989. $\kappa$-kaseine in Rindermilch -Nachweis eines weiteren Allels ( $\kappa-\mathrm{CnE}$ ) in verschiedenen Rassen. Journal of Animal Breeding and Genetics 106: 225-231.

Grandison, A. 1986. Causes of variation in milk composition and their effects on coagulation and cheesemaking. Dairy Industry International 51: 21-24.

- , Anderson, S.M., Ford, G.D., Newell L. \& Lyon-Smith, P. 1985. Effect of variation in the composition of milk supply on the composition and quality of farmhouse Cheshirecheese. Journal of Dairy Research 52: 573586.

Ikonen, T., Ahlfors, K., Kempe, R., Ojala, M. \& Ruottinen, O. 1999a. Genetic parameters for the milk coagulation properties and prevalence of non-coagulating milk in Finnish dairy cows. Journal of Dairy Science 82: 205-214.

-, Ojala, M. \& Ruottinen, O. 1999b. Associations between milk protein polymorphism and first lactation milk production traits in Finnish Ayrshire cows. Journal of Dairy Science 82: 1026-1033.

- , Ojala, M. \& Syväoja, E.-L. 1997. Effects of composite casein and $\beta$-lactoglobulin genotypes on renneting properties and composition of bovine milk by assuming an animal model. Agricultural and Food Science in Finland 6: 283-294.

- , Ruottinen, O., Erhardt, G. \& Ojala, M. 1996. Allele frequencies of the major milk proteins in the Finnish Ayrshire and detection of a new $\kappa$-casein variant. Animal Genetics 27: 179-181.

Jakob, E. \& Puhan, Z. 1992. Technological properties of milk as influenced by genetic polymorphism of milk proteins -a review. International Dairy Journal 2: 157178.

Kefford, B., Christian, M.P., Sutherland, B.J., Mayes, J.J. \& Grainger, C. 1995. Seasonal influences on Cheddar cheese manufacture: influence of diet quality and stage of lactation. Journal of Dairy Research 62: 529537.

Lawrence, R.C., Johnston, K. \& Honoré, C. 1993. Cheese yield, quality and profitability. In: Proceedings of a IDF Seminar Cheese yield \& factors affecting its control, Cork, Ireland. p. 529-538.

Lucey, J. \& Kelly, J. 1994. Cheese yield. Journal of the Society of Dairy Technology 47: 1-14.

Martin, B., Chamba, J.F., Coulon, J.B. \& Perreard, E. 1997. Effect of milk chemical composition and clotting characteristics on chemical and sensory properties of Reblochon de Savoie cheese. Journal of Dairy Research 64: 157-162.

Marziali, A.S. \& Ng-Kwai-Hang, K.F. 1986a. Relationships between milk protein polymorphisms and cheese yielding capacity. Journal of Dairy Science 69: 11931201.

- \& Ng-Kwai-Hang, K.F. 1986b. Effects of milk composition and genetic polymorphism on cheese composition. Journal of Dairy Science 69: 2533-2542.

Mayer, H.K., Ortner, M., Tschager, E. \& Ginzinger, W.
1997. Composite milk protein phenotypes in relation to composition and cheesemaking properties of milk. International Dairy Journal 7: 305-310.

Mitchell, G.E., Fedrick, I.A. \& Rogers, S.A. 1986. The relationship between somatic cell count, composition and manufacturing properties of bulk milk. 2. Cheddar cheese from farm bulk milk. Australian Journal of Dairy Technology 41: 12-18.

Nsofor, L. M. 1989. Syneresis and cheese yield of bovine milk with different chymosin coagulation properties. Journal of Food Science and Technology 26: 359-361.

Okigbo, L.M., Richardson, G.H., Brown, R.J. \& Ernstrom, C.A. 1985. Variation in coagulation properties of milk from individual cows. Journal of Dairy Science 68: 822-828.

Outinen, M., Tossavainen, O., Syväoja, E.-L. \& Korhonen, H. 1995. Chromatographic isolation of $\kappa$-casein macropeptide from cheese whey with a strong basic anion exchange resin. Milchwissenschaft 50: 570574.

Puhan, Z. \& Jakob, E. 1993. Genetic variants of milk proteins and cheese yield. In: Proceedings of a IDF Seminar on Cheese yield \& factors affecting its control, Cork, Ireland. p. 111-122.

Riddell-Lawrence, S. \& Hicks, C.L. 1989. Effect of curd firmness on stirred curd cheese yield. Journal of Dairy Science 72: 313-321.

Syväoja, E.-L. 1992. Quantitative determination of the main casein components and purification of $\alpha_{\mathrm{s} 2}-$ and $\kappa$-casein from bovine milk. Milchwissenschaft 47: 563-566.

- \& Korhonen, H. 1994. Determination of colostral immunoglobulins by gel filtration chromatography. International Dairy Federation Bulletin no 9404, Brussels, Belgium.

Tervala, H.-L., Antila, V. \& Syväjärvi, J. 1985. Factors affecting the renneting properties of milk. Meijeritieteellinen Aikakauskirja XLIII 1: 16-25.

Toivonen, M., Ojala, M. \& Pahkala, E. 1998. Effects of $\kappa-$ casein genotypes and milk renneting properties on yield and composition of fresh cheese. The $6^{\text {th }}$ World Congress on Genetics Applied to Livestock Production, Armidale, Australia. 23: 459-462.

Tong, P.S., Vink, S., Farkye, N.Y. \& Medrano, J.F. 1993. Effect of genetic variants of milk proteins on the yield of Cheddar cheese. In: Proceedings of a IDF Seminar on Cheese Yield \& Factors Affecting its Control, Cork, Ireland. p. 179-187.

Tyrisevä, A.-M., Ikonen, T. \& Ojala, M. 1999. Estimates of repeatability for and factors affecting the milk coagulation traits. The $50^{\text {th }}$ Annual Meeting of the European Association for Animal Production, Zurich, Switzerland, G6.11: 64.

Walsh, C.D., Guinee, T., Harrington, D., Mehra, R., Murphy, J., Connolly, J.F. \& Fitzgerald, R.J. 1995. Cheddar cheesemaking and rennet coagulation characteristics of bovine milks containing $\kappa$-casein AA or BB genetic variants. Milchwissenschaft 50: 492-496.

Zehren, V.L. 1993. Factors that affect yield over which cheese plant has control. In: Proceedings of a IDF Seminar Cheese yield \& factors affecting its control, Cork, Ireland. p. 245-260. 
Ikonen, T. et al. Effect of milk coagulation properties on yield and composition of cheese

\section{SELOSTUS}

\section{Tankkimaidon juoksettumisominaisuuksien vaikutus Emmental-juuston määrään ja koostumukseen} Tiina Ikonen, Outi Ruottinen, Eeva-Liisa Syväoja, Kimmo Saarinen, Eero Pahkala ja Matti Ojala
Helsingin yliopisto, Valio Oy ja Maatalouden tutkimuskeskus

Tutkimuksessa selvitettiin tankkimaidon juoksettumisominaisuuksien vaikutusta Emmental-juuston määrään sekä juuston ja juustoheran koostumukseen ja laatuun. Juustokoetta varten kerättiin 2-6 lypsykerran tankkimaidot yhteensä kahdeksasta karjasta, jotka muodostivat kaksi neljän karjan ryhmää. Ryhmän A karjat olivat tuottaneet kohtalaisen hyvin juoksettuvaa maitoa ja ryhmän B karjat huonosti juoksettuvaa maitoa. Hyvin juoksettuvaa maitoa tuottaneessa ryhmässä $\mathrm{A} \alpha_{\mathrm{s} 1}$-kaseiinin C-alleeli, $\beta$-kaseiinin $\mathrm{A}_{1}$ ja B-alleelit sekä $\kappa$-kaseiinin B-alleeli olivat yleisempiä, friisiläislehmien suhteellinen osuus oli suurempi ja maidon $\kappa$-kaseiinin, $\alpha$-laktalbumiinin ja $\beta$-laktoglobuliinin pitoisuudet olivat korkeammat kuin ryhmässä B.

Kummankin karjaryhmän tuottamasta maidosta valmistettiin kaksi Emmental-juustoa. Kunkin juuston valmistamiseen käytettiin noin 7401 maitoa. Ryhmän A hyvin juoksettuneesta maidosta saatiin keskimäärin 2 kiloa enemmän juustoa kuin ryhmän B huonosti juoksettuneesta maidosta. Tämä johtui pääosin siitä, että hyvin juoksettuneen maidon heraan hukkaantui vähemmän kaseiinia ja rasvaa kuin huonosti juoksettuneen maidon.

Tankkimaidon juoksettumisominaisuuksissa esiintyy runsaasti vaihtelua karjojen välillä. Tankkimaitojen juoksettumisominaisuuksilla oli vaikutus maidon käyttökelpoisuuteen juuston valmistuksessa. Tämän vuoksi maidon juoksettumisominaisuuksien pysyvä parantaminen on yksi edellytys juustontuotannon tehostumiselle. 